\title{
The First Notes About an Epistemological Orientation to the Law From the Relation Between Sensitivity and Understanding
}

\section{Primeiras Notas sobre uma Orientação Epistemológica ao Direito a partir da Relação entre Sensibilidade e Entendimento}

\author{
Vicente de Paulo Barretto \\ Universidade do Vale do Rio dos Sinos (UNISINOS) - Rio de Janeiro, RJ, Brasil
}

Jaci Rene Costa Garcia

Centro Universitário Franciscano (UNIFRA) - Santa Maria, RS, Brasil

\begin{abstract}
The article has the Kantian aesthetics as subject and proposes a study of reflecting judgment and its relation to critical hermeneutic ethics, having as main objective to investigate the critical hermeneutic ethics and its possibility to offer epistemological basis for the Law in contemporaneity. It was identified that it is possible to extend the reflecting judgment to the aesthetical field, even though the reflecting judgment is neither constitutive nor normative, once it contains a guiding function connected to the conformity principle to ends that serve as orientation for the cases evidenced in law area.
\end{abstract}

Keywords: Philosophy. Ethics. Law. Hermeneutics. Kant.
Resumo: O artigo tem como tema a estética kantiana e propõe um estudo do juízo reflexionante e de sua relação com a ética hermenêutica crítica, tendo como objetivo geral investigar a ética hermenêutica crítica e as possibilidades desta oferecer bases epistemológicas para o direito na contemporaneidade. Identificou-se que estender o juízo reflexionante para o campo da ética é possível, pois ainda que o juízo reflexionante não seja constitutivo e nem normativo, possui função orientadora ligada ao princípio da conformidade e a fins que podem servir de orientação para os casos que se apresentam em Direito.

Palavras-chave: Filosofia. Ética. Direito. Hermenêutica. Kant. 


\section{Introduction}

In what concerns to rationalist philosophy, this article mobilizes the reflecting judgment as a condition for a hermeneutics that lay its roots on the critique of judgment, allowing articulations that are organized from a research-orienting question: at what measure can a hermeneutical ethics offer an epistemological guidance for Law in contemporaneity?

The present study is delimitated as follows: [i] in one, from a philosophical approach unified by the Kantian critical system able to identify the preconditions for an epistemology that enables the achievement of judgments and [ii] in two, in the interception of understanding and practical reason from the postulates of aesthetic judgment, in particular, the reflecting judgment and [iii] in three, in the investigation about the possibilities of a critical ethics hermeneutic serve as epistemological guidance for the Law.

In summary, the given discussion involves determinant judgment and reflecting judgment, being the first as the difference allowing the delimitation of the second, and yet, by the reason of dissimilarities, both serve as auxiliary lines to clarify the problem in all its extension and complexity.

In this context, the pursuit is to find a critical hermeneutic ethics that permits to undo the apparent antinomy between knowledge production, deduced from pure postulates, and the comprehension ever immersed in historicity and traversed by sensibility: these two moments, apparently opposite, can be overcome by the entireness and the unity of Kant's work, allowing new perspectives for the comprehension of complex problems faced in the twenty-first century (ever since perpetrated by the human being in their worldly condition).

In this line, the reflecting judgment analysis and the route to the construction of a hermeneutical ethics must allow the identification of a new posture as per the problems faced by Law, from the epistemological orientation that will possibly be revealed by the survey. 


\section{The Embrionary Hermeneutical Ethics in the Critique of Judgment: the Relation Between Determinant and Reflective Judgments and the Aesthetics as Medium Between Freedom and Nature}

The problem faced when the Critique of judgment ${ }^{1}$ was started comprehends in itself a sample of the relation between determinant and reflective judgments, as the relation laid between causality (natural law) and finality (laws of freedom) involves postulates theoretical and practical reasoning apparently incompatible, since Kant warns that: “[...] if an immeasurable gulf is fixed between the sensible realm of the concept of nature and the supersensible realm of the concept of freedom." (KU, XX).

Yet in the initial part of this work, Kant says that even considering the passing from the realm of nature to the realm of freedom as impossible, the concept of freedom shall perpetrate in the sensible world the end imposed by its laws, or in other words, the sensible world must be conform to the purposes of freedom laws, under penalty of incongruence with the laws of freedom and make impossible the comprehension of the moral in the world.

The third critics great challenge is to find in the basis of nature the bond between the sensible and the supersensible, in Kant's words:

There must, therefore, be a ground of the unity of the supersensible, which lies at the basis of nature, with that which the concept of freedom practically contains; and the concept of this ground, although it does not attain either theoretically or practically to a knowledge of the same, and hence has no peculiar realm, nevertheless makes possible the transition from the mode of thought according to the principles of the one to that according to the principles of the other. $(\mathrm{KU}, \mathrm{XX})$

\footnotetext{
${ }^{1}$ With the Critique of Judgment (1790) ends the cycle of three Critiques: Critique of Pure Reason (1st Edition 1781 and 2nd Edition 1787) and Critique of Practical Reason (1788).
} 
It appears that by pointing out the impossibility of the concept of a foundation of the supersensible unity coming to achieve a knowledge seems to indicate, in a preliminary judgment, that Kant establishes the possibility of a bridge between nature and freedom as a type of belief ${ }^{2}$. Surely, what Kant wanted to say was that the laws of nature (in general) and the principle of casualty (in particular) may not become an obstacle to the action according to the laws ruling freedom, or in other words, the moral agent's practices need comprehension that lays unit and conformation to the principles of casualty (nature) and finality (morality). From Kant it is necessary to question where the interlude that permits the unification between the faculties of cognition and will ${ }^{3}$ is situated, both maintained by principles a priori ${ }^{4}$, speculating Kant that: “"

In the family of the higher cognitive faculties there is a middle term between the Understanding and the Reason. This is the Judgment, of which we have cause for supposing according to analogy that it may contain in itself, if not a special legislation, yet a special principle of its own to be sought according to laws, though merely subjective a priori. (KU, XXII)

\footnotetext{
${ }^{2}$ According to Kant, "To believe, or assent from a foundation objectively insufficient but subjectively sufficient, refers to objects $[. .$.$] about which we can merely be certain that it$ is not contradictory to think such objects in the way we do [...] is not an specific source of knowledge [...] We believe that the cause of the world also acts as a moral wisdom to the supreme good [...] This is the casus extraordinarius, without which, the practical reason cannot sustain itself in the relationship with its necessary end [...] "(Kant, 2003, p. 137-139).

${ }^{3}$ In the Critique of Pure Reason (cognitive faculty) the understanding gives, a priori, its law and within the framework of Practical Reason (appetitive faculty - will), assigns the reason, a priori, their law.

${ }^{4}$ Principles a priori are pure concepts that are defined as "pure is the concept that cannot be taken from the experience (Erfahrung) and even according to content (nach dem Inhalte), it arises from the intellect (aus dem Verstande) (Kant, 2003 p. 183) The concept opposes to intuition to be a universal representation or a representation of what is common to multiple objects, and thus a representation of the extent that can be contained in multiple ones (Kant, 2003, p. 181) As the concepts are divided into pure and empirical and are classified into universal, particular and singular categories, Kant warns "[...] It is mere tautology that we talk about universal concepts [...] it is not the concepts themselves, but only its use (Gebrauch) which can be divided this way. " (Kant, 2003, p. 181).
} 
So, with the faculty of judging - Usteilskraft - the middle point starts to be established and a bridge can built between nature (sensible) and liberty (supersensible). However, the following questions remains: which judgment would this be? Is it demonstrable? What Is its epistemological status? Is there a relation between it and hermeneutics or between it and moral?

At the moment, it is imperative to study a little more the differences between the determining judgments and the reflecting judgments. The first treaties relatively to critics and pure reason were carried out from the application of universal concepts to particular situations; the second ones, judgments generated from external contingencies looking for a unity around the concept ${ }^{5}$.

The search for the reflecting judgment in Kant comes from the observation that in nature there is a large number of laws that are not determined a priori, once Kant says that: “[...] as empirical, may be contingent from the point of view of our Understanding (KU, XXVII), being necessary to reflect on the ends, in Kant's actual words:

[...] As universal laws of nature have their ground in our Understanding, which prescribes them to nature (although only according to the universal concept of it as nature); so particular empirical laws, in respect of what is in them left undetermined by these universal laws, must be considered in accordance with such a unity as they would have if an Understanding (although not our Understanding) had furnished them to our cognitive faculties, so as to make possible a system of experience according to particular laws of nature. Not as if, in this way, such an Understanding must be assumed as actual (for it is only our reflective Judgement to which this Idea serves as a principle - for reflecting, not for determining); but this faculty thus gives a law only to itself and not to nature. (KU, XXVIII)

\footnotetext{
${ }^{5}$ Concept - in this contexto - must be understood as the possibility of unity of the multiple given into the experience.
} 
As seen, the reflecting judgment needs an intelligence in nature that contains purposes, found in an exercise (mental experiment) that aims to justify the reflection that permits the unification of these universes. The faculty of imagination - evoked in Kantian construction - allows the inception of an idea ${ }^{6}$ of finality for the innerness of the judgment, constituting a regulator principle, closing casualness and finality with the purpose of harmonizing as the laws of nature and freedom.

With this, there is a relation between imagination, understanding and sensibility ${ }^{7}$ in the Discovery (heuristics) of the principal of conformity for ends that serve as a middle term between natural casualness and moral finality, and, as investigated since Kant, an hermeneutics from aesthetics has (and it is what id defended) an epistemological and moral casing.

[...] This transcendental concept of a purposiveness of nature is neither a natural concept nor a concept of freedom, because it ascribes nothing to the Object (of nature), but only represents the peculiar way in which we must proceed in reflection upon the objects of nature in reference to a thoroughly connected experience, and is consequently a subjective principle (maxim) of the Judgement. Hence, as if it were a lucky chance favouring our design, we are rejoiced (properly speaking, relieved of a want), if we meet with such systematic unity under merely empirical laws; although we must necessarily assume that there is such a unity without our comprehending it or being able to prove it. (KU, XXXIV)

${ }^{6}$ The impression is what tries to build na architectural that allows some degree of organizations in the treaty of the question, being appropriate to demonstrate that the idea of freedom is for Kant an axiom, when he says that it cannot be conferred objective reality to any theory or this can be proved, except the idea of reedom, as it is certainly a condition of the moral law, whose reality is an axiom

${ }^{7}$ In the pre-critical studies it already appears the sensitivity setting to "receptivity of a subject, by which is possible that the representative status of it is affected in some way by the presence of some object. Intelligence (rationality) is the ability of a subject for which he has the power to represent what, by virtue of its quality, cannot fall his senses. The sensibility of the subject is sensitive; which, however, contains nothing but what is knowable by intelligence is intelligible. " (KANT, 2005, p. 235). 
In case the theme of reflective judgment is the beginning of the ending line, from the observation of nature and the organization of a living being takes Kant to state that "an organized product of nature is one where everything is order and vice versa middle. In it nothing is in vain, endless or attributable to a blind natural mechanism" (KU, $\S 66$, 296) "[...] identifying, thus, the principle of finality in the innermost of the beings organized within the (in short, in their own nature) and means. In it nothing is vain, without purpose, or to be ascribed to a blind mechanism of nature" (KU, $\S 66,296)$. If the theme of the reflecting judgment is the principle of conformity to ends, since the observation of nature and the organization of a living being leads Kant to assert: "[...] an organized product of nature is that in which everything is end and reciprocally means".

So, even though the principle of finality can be deducted from the experience of observation, nourished by a transcendentalism in face of a universality and necessity bore by the principle, as says Kant:

$[\ldots]$ is not a principle for the determinant but only for the reflective Judgement; that it is regulative and not constitutive; and that we derive from it a clue by which we consider natural things in reference to an already given ground of determination according to a new law-abiding order; and extend our natural science according to a different principle, viz. that of final causes, but yet without prejudice to the principle of mechanical causality. (KU, § 67, 301)

The Kantian reflection on $\S 67$ is to demonstrate that the elements of nature, separately in their manifestation do not permit the illation that there is a conformity with objectives, something that can only be hypothetically inferred from nature in its whole as a system according to the rule of the ends (KU, $\S 67,301)$, oriented by a subjective aphorism of reason (indemonstrable, then) which says that everything in the world is good for some purpose and that the nature is oriented by a conformity of purposes in its whole.

With this, Kant undoes any tensioning between determinism and the principle of conformity to ends, once the finality is a regulator 
principle (and not an understanding constituent principle), escaping from a relation of antinomy that could apparently involve the principles. Yet, it could be inferable that a reflecting judgment thinks to itself a regulator principle and - for being a judgment - it must be in some determinant moment, even though it only exerts a subsumption ${ }^{8}$ by concepts found in the reflection ${ }^{9}$ itself. Therefore, it is licit to conclude that the reflecting judgment has now by principle the power to reflect from the sensibility to the production of concepts not given a priori, constituting itself in a strategy for thinking concepts that are born from the empiric and, by force of the faculty of imagination, operating under the aegis of reflection, starts to constitute the conceptual universe that allows the judgment.

Pascal says that the intuitive understanding would have knowledge straight from nature as totality "[...] it would know the parts as ends, through its relation with the whole [...]" (PASCAL, 2011, p. 186), then the critics would fulfill a role in the transition between the sensible and the intelligible worlds, surging the third critics as a sort of mediator between the critics and the author, which will allow a more authentic contact with the experience. There is truly a "[...] primacy of the practical reason: the beauty and the harmony of this world have a moral meaning [...]" (PASCAL, 2011, p. 187), pointing out at an investigation of the basis of a hermeneutical ethics in the Kantian criticism.

This principle of conformity to end is born from the delight that the sensation of the external generates between the imagination and the understanding without the conceptual mediation, constituting itself in a direct relation with the pure reason from where ex surge a transcendental and unifying principle of the Kantian critical system (involving the preconceptual field not yet considered by the two other critics).

\footnotetext{
${ }^{8}$ It is understood as exerting a secondary subsumption.

${ }^{9}$ An example of the application is the analogy that rises from the usage of the reflecting faculty expressed in the relation that demonstrates that the aesthetic ideas are symbols of rational ideas. "[...] the Beautiful is the symbol of the morally Good, and that it is only in this respect (a reference which is natural to every man and which every man postulates in others as a duty) that it gives pleasure with a claim for the agreement of [251] every one else [...]." (KU, § 59, 258).
} 
The kind of relation that suits and - at the same time - suspends interests, may be portrayed in the most reliable by the definitions of the aesthetical judgments that Kant provides when he says that the beautiful

[...] is what pleases in the mere judgment (and therefore not by the medium of sensation in accordance with a concept of the Understanding). It follows at once from this that it must please apart from all interest. (KU, § 29, 115)

Having been demonstrated that the sensibility can unify the faculty of the understanding (pure reason) and conformity to ends (likewise?) as a reference for a moral feeling (practical reason), indicating that there is a unity of the Kantian system.

The sensation provoked by the externality conciliates with the pleasure of knowing, with the moral feelings and the feeling of life, which are/were explicitly admitted by $\mathrm{Kant}^{10}$ :

We no longer find, it is true, any marked pleasure in the comprehensibility of nature and in the unity of its divisions into genera and species, whereby are possible all empirical concepts, through which we recognize it according to its particular laws. However, this pleasure has certainly been present at one time, and it is only because the commonest experience would be impossible without it that it is gradually confounded with mere cognition and no longer arrests particular attention. (KU, XL)

It is valid to refer to Rodhen's conclusion (2009) when dealing with the first critic and relate to the third, once that it perfectly serves to this work, in particular at the identification of an original relation between cognition and appetition.

${ }^{10}$ The proper citation in the context of this work includes conclusive elements of the article "The transcendental function of Gemüt in the Critique of Pure Reason" Luiz Rodhen. The approach of equivalence between Gemüt (spirit) is taken to the end by Rodhen (2009). He says that the reference to Gemüt involves an open relation between knowledge and the other faculties. So that is why the reason, compared to an organism, articulates the knowledge as a human whole that remits to the fourth question inserted in the Logic "What is the man?" to which all the others can be deduced". 
What I want, therefore, propose on the whole of this presentation is to meet this Kant's warning, about the connection between knowledge and delight, and so a new sense to Goethe's dicotomic sentence is given According to what was seen so far, I would say in reference to this sentence by Goethe, a Kant's broad reader: the theory Is grayish if it lost relation with life. At this measure it becomes trivialized and bureaucratic and stops being creative. As, on the contrary, it wants to keep its creativity, what involves a relation between the theory and the delight of knowing, at this measure we will be able to say that the theory is no longer grayish. And the knowledge, thought in the critics of pure reason compared to a tree, will then recognize itself as the golden tree of knowledge.

Bringing up Rodhen's work to discussion helps the research when it deals with the epistemological orientation present on the third critics, has to do with the proposition of this work, once it Rodhen states that human mood, admitted in the critics of judging faculty as a principle of life, has direct and fertile bond with level of production of human knowledge.

For Kant the relation with life is given by the feeling of life (Lebensgefühl) that, for beyond of allowing a relation of continuity between Kant and Dilthey - presents itself as an elementary truth, pointing out Schmidt (2001) that our comprehension of the original and more deep sense of truth starts by this feeling ${ }^{11}$ (feeling of life).

\section{Critical Hermeneutical Etics: a Proposal of Conill Sancho from the Critics of Judgment and Antropology from a Prag- matic Point of View}

Coniil Sancho names different contemporaneous authors who deal with hermeneutics under its diverse perspectives (Rawls, Taylor, Gadamer, Apel, Habermas, among others, bringing up a feeling of strangeness that such authors, even though dealing with moral philosophy

\footnotetext{
${ }^{11}$ On the sense of life, says Schmidt (2001, p. 44) from Kant: this movement at the center of an aesthetic experience is really the opening of what we call true (this movement that is at the center of esthetic experience is really the opening up of that which we must call true).
} 
and politics, do not engage in a particularized study of an hermeneutical ethics. Within this context, the question that orients this research rises: is the existence of an authentic hermeneutical critical ethics that attends both irrevocable sides, logos and experience possible?

Conill Sancho's ${ }^{12}$ proposal presupposes a relation between Kant's hermeneutics and, as a way to that, elects "Gademerian way" which besides pass through Schleirmacher and Dilthey, has in its base Heideggerian hermeneutics of facticity. The path elected to undertake the work of finding philosophical-hermeneutical Kantian's roots faces objection in Gadamer, which are, at first identified: [a] Gadamer understands that the Critics of Kantian Judgment incur in subjective deviations that are not suitable to offer a model for the hermeneutical thought; [b] following Heidegger's line of thought, Gadamer's hermeneutics would be incompatible with an ethics engendered in modern critical spirit; [c] there is a centrality of ethics in the "Gadamerian way" (from Dilthey to Gadamer, passing through Heidegger), prevailing the aesthetic and ontological interest.

Once Gadamer draws the attention for the subjectivity present in the aesthetics judgment, it is sharpened the need of becoming aware of the necessary care when any advance is proposed, taking as a highly complex system as the Kantian philosophy as a base, being appropriated yet again to refer to Hamm, that repeats Kant when says that "there cannot be a constitutive concept for the beautiful" (HAMM, 2000, p. 51), in view that the theory of aesthetics judgment is assented on the aesthetic experience and then "necessarily implicates the renouncement - which, indeed, is a deliberated renouncement - on one hand the idea of work while "possessing" or "generating" of truth, as well any domination of art by general concepts (HAMM, 2000, p. 51).

\footnotetext{
12 The work 'hermeneutics Ethics': Crítica desde la facticidad Jesus Conill Sancho (2006) is divided into three major parts: the first revolves around the question about the possibility of a hermeneutic ethics; the second, on the relationship between hermeneutics and factuality; the third, in the critique of a pure hermeneutic ethics, identifying a strong influence Kantian throughout the work. On this topic, the considerations are general and consider the entirety of the work.
} 
This questions about the impossibility of truth for Gadamer reaches larger extension, which will found its hermeneutics that is also not dominated by the concept (even though it does not renounces the truth), specifically when It says that the starting point of his hermeneutical theory was the masterpiece, considering that art is constituted under a "[...] provocation to our comprehension, because it always takes our interpretations away and opposes itself with an insurmountable resistance to be overcome by the identity of the concept" (GADAMER, 2002a, p. 15).

Investigating Conill Sancho's proposal a pretension of connecting Kant hermeneutics specially from two other Kantian ${ }^{13}$ Works can be identified: [a] Critics of judgment, in which the capacity of judging excels, a new capacity of judgment, a new functions of imagination ${ }^{14}$ and a subjacent idea of life; [b] Anthropology in a pragmatic sense, where Kant brings up a "aesthetics of freedom" and a logical-practical methodology, which, aside the capacity of judging constitutes a base for a new model of applying the ethics, in Conill's words a pragmatic of freedom.

Drawing a parallel between the first critique [...] and the third [...], Coniil will emphasize the importance of imagination for the Kantian philosophy, once in the first critique [...] the imagination is at the understanding service, making possible synthetic judgment a priori that will allow the comprehension of scientific nature, contributes for the interpretation of experience and makes its way for the hermeneutical process. Once the third critique brings a reflecting capacity of judging,

\footnotetext{
${ }^{13}$ Following the same line, he criticizes Gadamer's interpretation that "[...] it is due to deficient study of the Kantian thought, when not considering relevant contributions coming specially from the critics of judgment, from metaphysics of costumes and the anthropology in its pragmatic sense" (SANCHO, 2006, p. 64).

${ }^{14}$ The faculty of imagination appears at the beginning of Critics of Judgment when Kant, treating of the analytics of the beautiful, infers that the judgment of taste is an aesthetical judgment (and not a logical judgment), asserting that: "When we say if something is beautiful or not, we relate the representation, not by the understanding of the aimed object towards the understanding, but by imagination (perhaps associated with understanding) towards the subject and the feeling of liking or disliking experienced by it." (KU, p. 47).
} 
an orienting and interpretative function is obtained, moving away from a legislative function, which appears in the first and in the second critique.

Conill Sancho highlights that even though the reflecting judgment is more free and allows that imagination creates its own ideas to organize the experience - there are not many works extending the Kantian theory of the critique of the judgment in addition to the problems of taste ${ }^{15}$ and its finality in nature (he cites as instance, Hanna Arendt, on footnote 4, mentioning her work where the conditions of the reflecting judgment is applied on the analysis of the political judgment).

To defend the thesis of hermeneutics from the third critique (CJ), Conill Sancho cites that in the sublime feeling the imagination changes from apprehension to an aesthetic understanding, instantly capturing the multiplicity as a unit, given that the holistic approach points to a transcendental philosophy enabling a more integral view of man. To Conill, the aesthetic in Kant's system is not in a secondary place, bringing hermeneutical function of mediation between understanding and reason, resulting in orientation: according to the philosopher, nor deduction neither induction, but an interpretive understanding that is based on a harmonious movement of faculties.

Conill Sancho will also identify that the feeling of life - morally interpreted - could be considered the aesthetic manifestation of transcendental freedom, presenting as associated the feeling of respect as an aesthetic manifestation of rational consciousness of the moral law. Accordingly, in Kant's existence can be felt and even though it may not be conceptualized, its anteriority and its unique relationship with the sentiment cannot be moved away. From this perspective, one can reflect on the continuity of relationship between Kant and Dilthey, as for Conill

${ }^{15}$ Makkreel sutains the relevance of the Kantian Philosopy for the hermeneutics since a na epistemological unit between critique and reason can be found, widening the epistemological concept and allowing a critical hermeneutics. (MAKREEL, 1990, p. 2) The unity between aesthetics and cognition (see footnote 15) have been held in the contemporaneity by both the semiotic and the hermeneutics under Gaddamerian's view, leaving not sufficiently answered if [i] the critical Kantian system allows such a relationship and [ii] if it is possible a hermeneutics criticque compatible with the idea of a guiding ethics. 
Sancho Kant's work already announces an incipient philosophy of life, once he believed that life could only be felt but could not be known. Kant and Dilthey agree that life is primarily accessible through feeling and Conill Sancho concludes that [i] the usage of the Kantian concept of life in the Critique of Judgment demonstrates the continuity on the work Critique of historical reason by Dilthey and [ii] the philosophy of life in Dilthey seeks historical self-reflection (selbstbesinnung), it should be considered as an enlargement of the principle of Kantian ${ }^{16}$ reflective judgment.

Conill Sancho's main point is to discover the mediation between hermeneutics (conditionality, historicity) and critique (absoluteness, universality), to understand a practical reason, historically conditioned and capable of unconditioned ethical principles, in other words, the possibility of validity of an impure universalization (therefore historic and practical). Wellmer's proposition is cited (CONILL SANCHO, p. 213), which argues that an unconditioned ethical law, as Kant's categorical imperative, does not need be thought of as a "fact of the reason", but should be thought of as "fact of a life under the conditions of the reason", being sufficient that it demonstrates itself as a historical way of life governed by reason. Conill drags the temporality of the being to the temporality of reason, joining being, logos, sense of life, allowing then an hermeneutic universalism to be postulated.

A hermeneutical critic ethics as Conill Sancho intends is a project that, even though seeking its fundaments in the Kantian criticism, advances and rebuilds from a radical fresh start from Kant. If the proposed

\footnotetext{
${ }^{16}$ Although this is not the subject of this study, it is important be noted that the various "classifications" of semiotics operate towards direcionarem aesthetic systems to cognitive systems also being Cognitivism object and linguistic study of reflective judgment, demonstrating that after Kant logic (both formal and transcendental) loses ground to the cognition of the tract on another plane, mentioning that Piaget brings studies on reflective abstraction, "psychologically, each new reflection assumes the formation of a higher level of" reflexionamento "where the remaining in the lower level, as a tool in the service of thought in the process, becomes an object of thought and is therefore themed, rather than stay in instrumental state or operation [...] New heights of "reflexionamentos "are built, so incessantly, to allow new Reflections [...]. (PIAGET, 2005, p. 275).
} 
new beginning is sufficiently authorized by the continent philosopher, it is a discussion that overflows the narrow limits of this research.

\section{Conclusion}

The question is redefined at the end: after all, is it possible to extend the reflective judgment to the field of ethics and law? Considering the available evidence, it is about directing an aesthetic system to a cognitive system, where the game among reason, understanding and sensitivity is redefined, being the last one mentioned as a mediator of the process of understanding. In this sense, Conill Sancho's proposition is to innovative and places ethics at the center, lending itself with a guiding role in this reflective judgment, to serve as guidance for the cases that arise in law. At last, to conduct a pragmatic study of the application would also be beyond the limits proposed by the theme, and that internalization of the hermeneutical model, alone, has a pragmatic reach for [i] represent a new relationship with the externality and [ii] always involves the interpreter behavioral change (leaving evident in cases where there is an enclosure in a positivist model).

A few more conclusions can be made explicit:

$1^{\mathrm{o}}$ The determinant judgments were the object of the Critique of Pure Reason and its accomplishment from the application of universal concepts to specific situations; the reflecting judgments (Critique of Judgment) come from the conclusion that in nature there is a large number of laws that are not determined a priori, and such external contingencies seek unity in the concept that needs to be found.

$2^{\circ}$ Finality is a regulative principle corollary of the reflective judgment (if it is not a constitutive principle of understanding), escaping from a relation of antinomy that would apparently involve the principles (purpose and causality).

$3^{\circ}$ The reflective judgment takes on as a principle the power to reflect from the sensitivity to produce concepts/universal not given a priori, constituting itself a strategy to think about concepts that are born of the 
empirical and, under the imaginative faculty, operating under the aegis of reflection, they constitute the conceptual universe that allows the judgment.

$4^{\circ}$ The aesthetic reflection is at the basis of hermeneutics both in Dilthey as in Gadamer, represent a break with the domination of the concept, accordingly, serves to question the instituted and to serve as a guide to the unveiling of the sense.

$5^{\circ}$ Taking into account that the decisions in law invariably involve a judgment with creative power that enables weighting from the externality (not yet normatively set), the reflective judgment can serve as epistemological orientation for the studies of cases.

$6^{\circ}$ The reflective judgment as an instrument at the service of critical hermeneutics ethics allows the multiple given the experience to climb (internalization) and condense from the vivification: reflected concepts that feed back into these practices arise. This process tends to infinity and is only possible [i] by the inherent purpose of the judgment and [ii] the ethical link that generates "weak normativity" that externalizes as guidance (thread). This is the meaning of a critical-hermeneutical ethics: to know that there is an ethics defining the outlines, designing senses and ensure objectivity to the judgments stated before the events of the world.

With that, submitted to the outlines of facticity and historicity, more and more human and social sciences need to dialogue with the processes born from complex reality and be able to produce appropriate responses, enabling the inference that the construction of meanings is becoming more dependent on the reflection (and its levels) as well as on ethical foundations that need to integrate the hermeneutical process.

\section{References}

CONILL SANCHO, Jesús. Ética Hermenéutica: crítica desde la facticidad. Madrid: Editorial Tecnos, 2006.

DILTHEY, Wilhelm. A construção do mundo histórico nas ciências humanas. Tradução de Marco Casanova. São Paulo: Editora UNESP, 2010. 
GADAMER, Hans-Georg. Entre fenomenologia e dialética: tentativa de uma autocrítica. Petrópolis: Vozes, 2012. Verdade e método I,

. Entre fenomenologia e dialética: tentativa de uma autocrítica. Petrópolis: Vozes, 2011. Verdade e método II.

HABERMAS, Jürgen. Consciência moral e agir comunicativo. 2. ed. Rio de Janeiro: Tempo Brasileiro, 2003.

HAMM, Christian. A hermenêutica da consciência estética: anotações sobre a teoria de Gadamer. In: REIS, Róbson Ramos dos; ROCHA, Ronai Pires da. Filosofia hermenêutica. (Org.) Santa Maria: Ed. da UFSM, 2000.

KANT, Immanuel. Crítica da faculdade do Juízo. 2. ed. Tradução de Valério Rohden e Antonio Marques. Rio de Janeiro: Forense Universitária, 1995.

KANT, Immanuel. Critique of Judgement. 2. ed. Translated with Introduction and notes by J. H. Bernard. Macmillan Company, London, 1914.

. Escritos pré-críticos. Tradução de Jair Barboza et al. São Paulo: Editora UNESP, 2005.

. Manual dos Cursos de Lógica Geral. 2. ed. Tradução: Fausto Castilho. Campinas, SP: Editora da Unicamp, 2003.

MAKKREEL, Rudolf A. Imagination and Interpretation in Kant: the hermeneutical importo of the Critique of Judgment. Chicago: Chicago Press, 1990.

PASCAL, George. Compreender Kant. 7. ed. Petrópolis: Vozes, 2011. PIAGET, Jean. Seis estudos de psicologia. Rio de Janeiro: Forense Universitária, 2005.

RODHEN, Luiz. A função transcendental do Gemüt na Crítica da razão pura. Kriterion, Belo Horizonte, v. 50, n. 119, 2009. Disponível em: $<$ http://www.scielo.br/scielo.php?pid=S0100512X2009000100001\&script=sci_arttext $>$. Acesso em: 27 nov. 2014. 
SCHIMIDT, Dennis J. On the idiom of Truth and the Movement of Life. In: FIGAL, Günter (Hg). Internationales Jahrbuch für Hermeneutik. Schwerpunkt: 50, Jahre Wahrheit und Methode. Mohr Siebeck, 2011. p. 41-53.

STEIN, Ernildo. Racionalidade e Existência. 2. ed. Ijuí: Editora Unijuí, 2008. Unijuí, 2001.

. Epistemologia e Crítica da Modernidade. 3. ed. Ijuí: Editora WITTGENSTEIN, Ludwig. Philosophical Investigations [Investigações Filosóficas]. Bilíngue Alemão/Inglês. G. E. M. Anscombe \& Rush Rhees (Ed.). Trad. G. E. M. Anscombe. Oxford: Blackwell, 2000.

Jaci Rene Costa Garcia possui graduação em Direito (1992), mestrado em Filosofia pela Universidade Federal de Santa Maria (2002) e doutorado em Direito pela Universidade do Vale do Rio dos Sinos (2015). Realiza estudos no programa de pós-doutorado em Filosofia da UNISINOS (2017) sob a supervisão do Professor Dr. Luiz Rohden. É professor adjunto do Centro Universitário Franciscano (UNIFRA). E-mail: garcia@garcias.com.br.

Endereço profissional: Centro Universitário Franciscano, Centro de Ciências Sociais Aplicadas, Direito. Rua dos Andradas, 1614 Centro - Santa Maria, RS Brasil. CEP: 97010-032

Vicente de Paulo Barretto é pós-doutor pela Maison des Sciences de L'Homme, Paris. Livre-docente em Filosofia pela PUCRJ, 1976. Possui graduação em Direito pela Universidade do Estado da Guanabara (1962). Professor do Programa de Pós-Graduação em Direito da UNISINOS. Decano da Escola de Direito da UNISINOS.

E-mail: vpbarreto@terra.com.br.

Endereço profissional: Universidade Estácio de Sá, Centro de Ciências Jurídicas. Rua São José, 35/15 andar. Centro - Rio de Janeiro, RJ - Brasil. CEP: 20010-020 